\title{
Human intestinal mucosal mast cells: expanded population in untreated coeliac disease
}

\author{
S STROBEL, ${ }^{*}$ A BUSUTTIL, AND ANNE FERGUSON \\ From the University of Edinburgh Gastro-Intestinal Unit, and Department of Pathology. Western General \\ Hospital, Edinburgh
}

SUMmaRY Previous retrospective studies of intestinal mucosal mast cells in coeliac disease have given divergent results, and we have recently reported that inappropriate methodology could account for these discrepancies. In this prospective study, mucosal mast cell counts were performed in Carnoy fixed, peroral jejunal biopsy specimens from patients with coeliac disease, both untreated and treated with a gluten-free diet; and from controls (mainly irritable bowel syndrome). Mean mucosal mast cell count in 27 control subjects was $146 / \mathrm{mm}^{2}$, SD 29 . Significantly higher values were obtained in untreated coeliac disease (mean 243, SD 41, $\mathrm{p}<0.001)$ returning to the normal range in coeliacs treated with a gluten-free diet with normal jejunal biopsy morphology. In seven patients mucosal mast cell counts were performed in multiple jejunal biopsies, and these showed that mucosal mast cell distribution was not patchy. There was no evidence of degranulation of intestinal mucosal mast cells under the conditions of routine biopsy (overnight fast). An increase in mucosal mast cells in untreated coeliac disease may be one explanation for the high number of IgE positive stained cells in the intestinal mucosa that has been reported by some authors.

Within the complex cellular infiltrate of jejunal mucosa, there is a population of mucosal mast cells. It has been suggested that degranulation of these intestinal mucosal mast cells may play a part in the pathogenesis of the clinical symptoms in food allergic diseases in the broadest sense such as coeliac disease $^{12}$ and cow's milk protein intolerance. ${ }^{2}$ Evidence to support this postulate is scanty. There are three reports of mucosal mast cell counts in coeliac disease. Kumar and her colleagues ${ }^{3}$ reported values to be higher than normal in untreated coeliacs, remaining high after after treatment with a gluten-free diet: in another report counts were said to be low in untreated coeliac disease, returning to normal after gluten withdrawal, ${ }^{1}$ and a third study (published in abstract) reported low mucosal mast cell counts in untreated coeliac disease, values remaining lower than normal after treatment. ${ }^{4}$ These discrepancies may be due to methodological errors in retrospective analysis of formalin-fixed jejunal biopsy specimens. We have recently

\footnotetext{
* Address for correspondence: Dr S Strobel. Gastro-Intestinal Unit. Western General Hospital. Edinburgh EH4 2XU.

Received for publication 8 June 1982
}

reported the critical role of fixative on mucosal mast cell counts in normal human jejunal biopsies. ${ }^{5} \mathrm{We}$ therefore performed a prospective study of mucosal mast cell counts in peroral jejunal biopsies and have studied coeliac patients, together with other patients having jejunal biopsy (usually for investigation of diarrhoea).

\section{Patients}

PATIENTS STUDIED

Peroral jejunal biopsies from an unselected group of 57 patients were studied. Biopsy had been performed for diagnosis or follow-up of coeliac disease, or to exclude lactase deficiency as a factor in patients with irritable bowel syndrome or diarrhoea. In these patients, jejunal biopsy was taken with a Watson peroral biopsy capsule after an overnight fast. The biopsy was taken just distal to the ligament of Treitz, and divided into three parts; one was fixed in formalin for routine diagnostic pathology, one for disaccharidases estimation, and the third piece was fixed in Carnoy's fixative for mast cell counts. Nineteen biopsies were from coeliac patients, showing subtotal or severe partial villous atrophy, 
and had generalised disaccharidase deficiency; in 11 cases, biopsies were from coeliacs treated with a gluten-free diet and were histologically normal with normal disaccharidase activities; and there were 27 biopsies from patients with irritable bowel syndrome or in whom coeliac disease was ultimately excluded; all of these patients were taking normal diet, and in all cases both histopathology and disaccharidase content of the biopsies were normal.

In seven patients multiple jejunal biopsies were taken with a Quinton hydraulic biopsy instrument. These were patients with malabsorption or diarrhoea in whom a patchy distribution of jejunal abnormality was suspected. Final diagnoses are given in the Table. Several biopsies were taken at each of three to five sites along the proximal jejunum, and one sample from each site was fixed in Carnoy's fixative.

\section{STAINING PROCEDURE}

After Carnoy fixation (minimum fixation time six hours) the tissue was paraffin embedded, $6 \mu \mathrm{m}$ sections cut, and mucosal mast cells were stained with Astra blue/safranin at $\mathrm{pH} 0.3$ as previously described. ${ }^{56}$

\section{METHOD FOR MAST CELL COUNTS}

Mast cells were counted in well-orientated sections cut perpendicular to the mucosa. The counts were performed on coded slides on a Leitz Dialux 20 EB microscope (eyepiece $\times 10$, objective $\times 40$ ). A 100 $\mathrm{mm}^{2}$ eyepiece graticule, calibrated against a calibration slide, was used. The edge of the graticule was orientated along the muscularis mucosae at the base of the crypts. The area covered by the square of the graticule comprised $80-100 \%$ of the total depth of the mucosa (from the bottom of the crypt to the tip of the villus). For each biopsy, a minimum of 10 fields $\left(290 \mu \mathrm{m} \times 290 \mu \mathrm{m}\right.$; area $\left.0.084 \mathrm{~mm}^{2}\right)$ were counted and the mucosal mast cell count per specimen was expressed as mucosal mast cells $/ \mathrm{mm}^{2}$. No attempt was made to correct for the area covered by epithelium or lying between villi. This technique is similar to the mucosal unit counts, as applied to plasma cell counts. ${ }^{7 "}$

\section{STATISTICS}

Results for the various groups were analysed by using Student's $t$ test for unpaired observations.

\section{Results}

As in our previous work with operative biopsies of jejunum, the technique used gave excellent staining of mucosal mast cells in peroral jejunal biopsy specimens (Figs 1, 2). In those biopsies which contained muscularis mucosa with some submucosa, there was a difference in the staining patterns between the submucosal and mucosal (lamina propria) mast cells, the granules of the former being more intensely stained than those of lamina propria mucosal mast cells. This is further evidence supporting the existence of at least two different mast cell populations in the jejunum. ${ }^{10}$ "1 Intraepithelial granulated lymphocytes were not identified, even under oil immersion $(\times 100)$ in these jejunal biopsy specimens, although we had found such cells in operative jejunal biopsies. ${ }^{5}$ These findings highlight again the importance of optimal methodology and the problems of comparing features of surgical biopsies with biopsies taken perorally.

Intraepithelial mast cells were occasionally seen (Fig. 3), their numbers being too small to allow any measurements of prevalence within a group of biopsies. A single mast cell in mitosis was found in a patient with untreated coeliac disease (Fig. 4) and in no patient was degranulation of mast cells observed.

\section{MUCOSAL MAST CELL COUNTS IN MULTIPLE \\ BIOPSIES OF JEJUNUM}

Results for mucosal mast cell counts in the seven patients who had multiple biopsies are summarised in the Table. Diagnoses ranged from normal to

Table

\begin{tabular}{|c|c|c|c|c|c|c|}
\hline \multirow[b]{2}{*}{ Diagnosis } & \multicolumn{6}{|c|}{$M M C / m^{2}$ at various sites in proximal jejunum* } \\
\hline & 1 & 2 & 3 & 4 & 5 & Histology \\
\hline Diarrhoca - lactase deficiency, previous radiotherapy & 128 & 146 & 135 & 141 & 149 & Normal \\
\hline Severe diffuse enteritis & - & 150 & 165 & 139 & 174 & Normal \\
\hline Coeliac, recently started on gluten-free diet & 201 & 183 & 163 & 180 & 173 & Subtotal villus atrophy \\
\hline Delayed recovery from giardiasis & 180 & - & - & 200 & 230 & Partial villus atrophy \\
\hline Functional diarrhoea & 134 & - & 160 & 130) & - & Normal \\
\hline Relative of coeliac - lactase deficiency & 107 & 120) & - & 123 & - & Normal \\
\hline Coeliac on normal diet & 267 & - & - & 258 & 235 & Partial villus atrophy \\
\hline
\end{tabular}

* Site 1 at ligament of Treitz; other biopsies at approximately $10 \mathrm{~cm}$ intervals beyond the ligament of Treitz. 
Fig. 1 Jejunal biopsy histologically normal mucosa. Several intensely stained mucosal mast cells can be identified, even at low magnification. Most mucosal mast cells are confined to the lamina propria around the crypts and in the lower part of the villi. The arrow indicates the cross-section of mucosal mast cells. Carnoy's, $A B / S p H$ $0 \cdot 3, \times 160$.

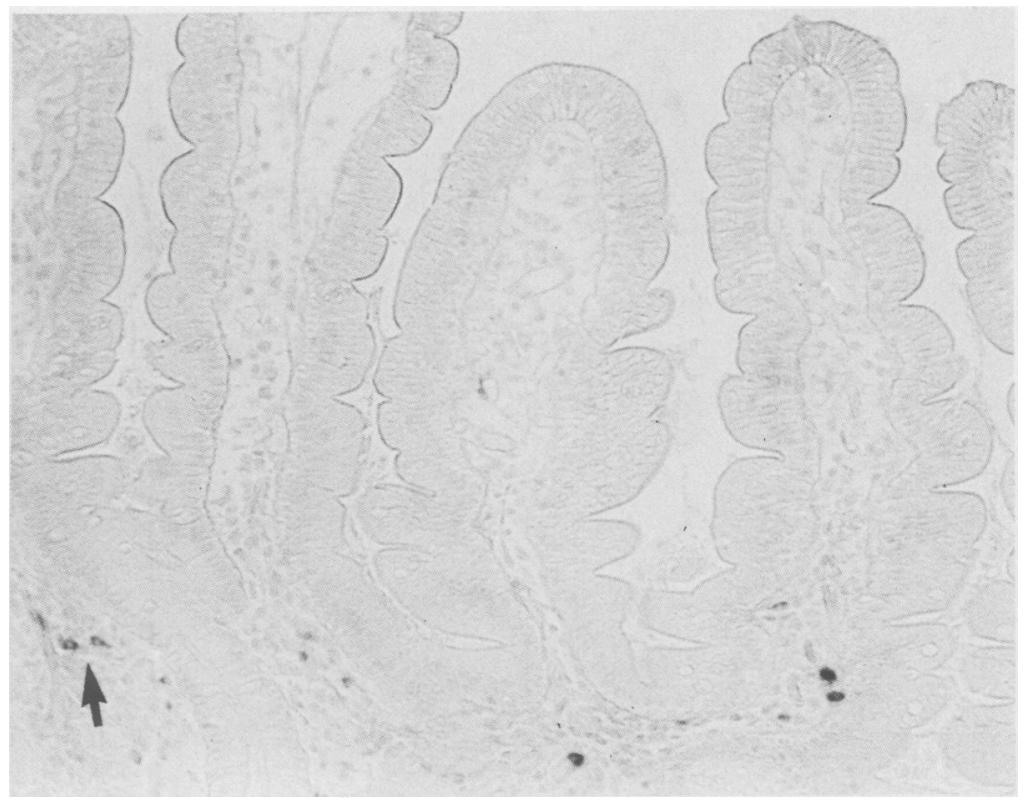

untreated coeliac disease, and, as indicated, similar mucosal mast cell counts were obtained at the various sites in each of the patients.

\section{MUCOSAL MAST CELL COUNTS IN COELIAC}

DISEASE AND CONTROLS

Results of the mucosal mast cell counts in biopsies obtained with the Watson capsule are given in Fig.
5. In the controls, mean mucosal mast cell count was $146\left(\mathrm{SD} 29 / \mathrm{mm}^{2}\right)$. In untreated coeliac disease significantly higher values were obtained $(243 \pm 41$, $\mathrm{p}<0.001)$ and, with patients with normal jejunal morphology on a gluten-free diet, the value was similar to normal subjects $(145 \pm 26)$ and significantly lower than in the untreated coeliac patients $(p<0.001)$.
Fig. 2 Jejunal biopsy-coeliac disease with severe partial villus atrophy. Many mucosal mast cells can be seen as partly dark stained cells, even under low power. Carnoy's, $A B / S$ pH $0 \cdot 3$, $\times 160$.

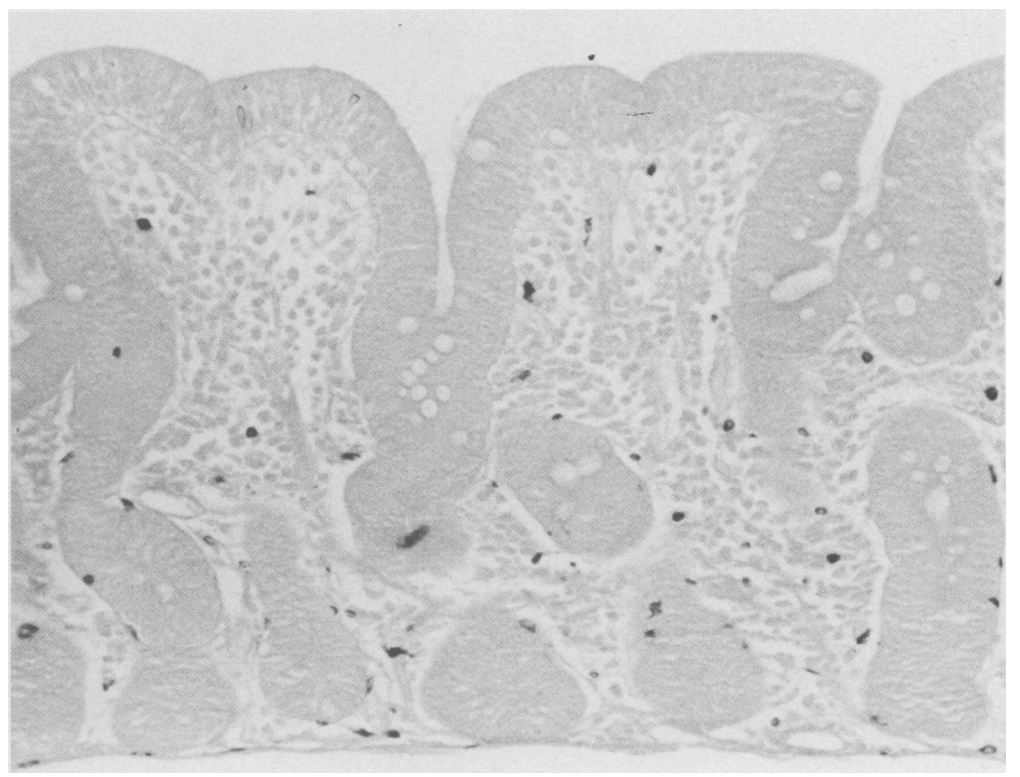




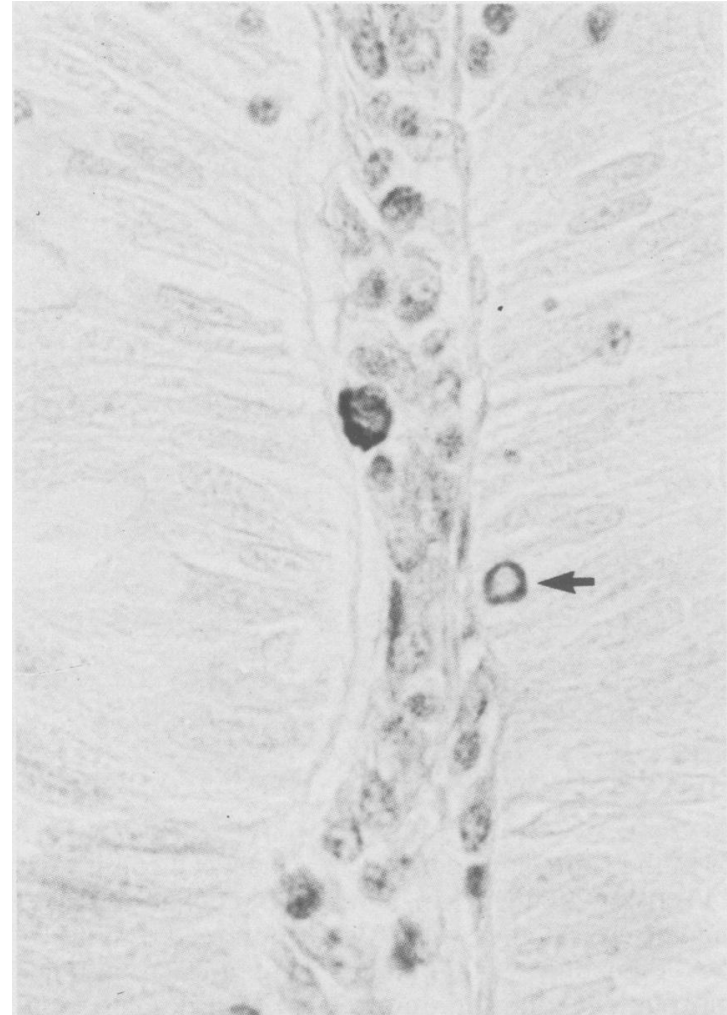

Fig. 3 One intraepithelial and one lamina propria mast cell (arrowed) in a biopsy of histologically normal jejunum. Carnoy's, $A B / S$ pH 0.3, $\times 750$.

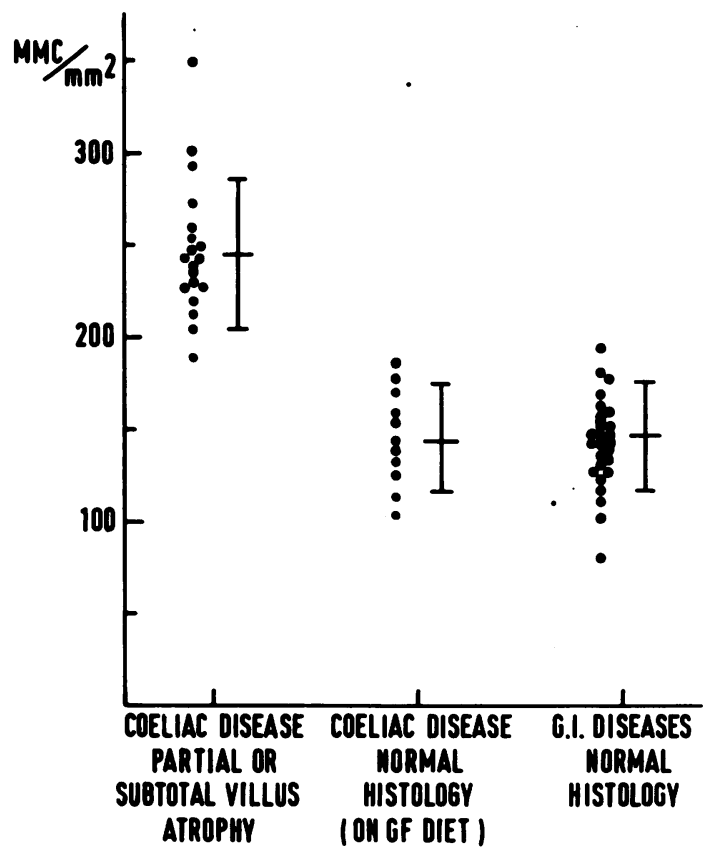

Fig. 5 Mucosal mast cell counts $\left(M M C / \mathrm{mm}^{2}\right)$ in patients with coeliac disease, either with partial or subtotal villus atrophy, or with normal jejunal morphology on a glutenfree diet; in control patients with normal histology and disaccharidases.
Fig. 4 Mucosal mast cell in mitosis (arrowed) from a jejunal biopsy of a coeliac patient. In the upper left corner of the preparation is a normal, non-dividing mucosal mast cells. Carnoy's, $A B / S p H 0 \cdot 3$, $\times 875$.

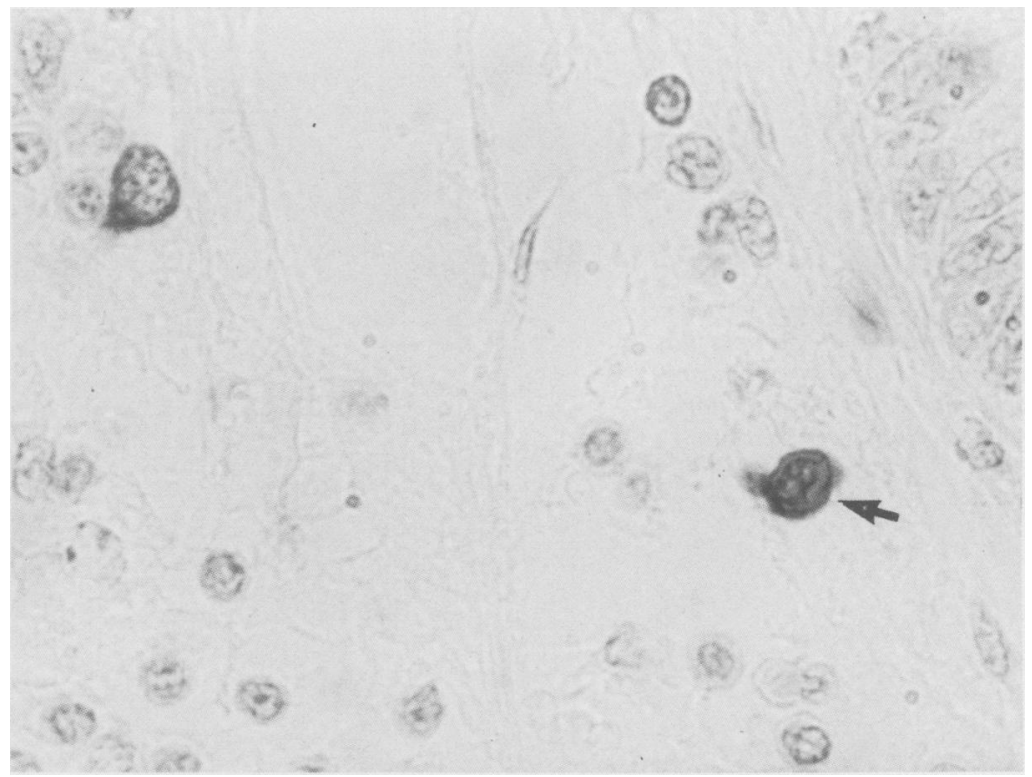




\section{Discussion}

In this prospective study of intestinal mucosal mast cells, we have demonstrated that the population of these cells is expanded in untreated coeliac disease. and that counts return to normal after successful treatment with a gluten-free diet. In order to perform this study, it was necessary to divide peroral jejunal biopsy specimens, and use different fixatives for diagnostic histopathology and for mucosal mast cell counts. It seems likely that the discrepant results in the literature for mucosal mast cell counts in coeliac disease $\mathrm{s}^{1.34}$ are attributable to inappropriate methodology in these earlier studies; these were retrospective reviews of tissues which had been processed for diagnostic purposes, and there is no indication that, in any of these studies, Carnoy's or a similar fixative, suitable for demonstration of mucosal mast cells, had been used. In two of the three previous reports, mast cell counts in formalinfixed specimens from coeliac patients were said to be lower than in controls. As we have now unequivocally shown that there are more mucosal mast cells in coeliacs, these earlier observations must have been due to differences between coeliacs and normal subjects in the susceptibility to the fixative-associated blocking which impairs histochemical staining of mast cell granules in formalinfixed mucosal biopsies. This may imply that, in coeliac disease, the mucosal mast cells are a younger, still dividing cell population, ${ }^{12} 13$ cells which would have a lower glycosyl-aminoglycan content.

We failed to find any evidence of degranulation of intestinal mucosal mast cells - another postulated explanation for a low mucosal mast cell count in tissue sections. ${ }^{14}$ It has been claimed that this phenomenon occurs in coeliac disease ${ }^{2}$ and in Crohn's disease. ${ }^{14}$ The morphology of mucosal mast cells in untreated coeliac disease, however, appeared to be identical with that in treated coeliacs or in normal controls. Nevertheless, mast cell mediators could still contribute to mucosal damage even in coeliac disease, for intestinal mucosal mast cells are known to have the capacity to secrete mediators without visible evidence of degranulation. ${ }^{210}$ Other workers ${ }^{15-17}$ have approached the question of degranulation of mucosal mast cells by functional studies rather than by histopathology, and have estimated tissue contents of 5-hydroxytryptamine ${ }^{15}$ or histamine ${ }^{16}$ in coeliac disease or Crohn's disease. ${ }^{17}$ Increased levels of these constituents have been found in homogenised tissue preparations, findings in complete agreement with our demonstration of an expanded mucosal mast cell population in coeliac disease, although the sources of increased histamine or 5-hydroxytryptamine levels - mucosal mast cell or non-mast cell origin - are still unclear.

IgE-containing cells - the nature of which is unspecified - have been reported to be increased in number in coeliac disease. food allergic disease, and inflammatory bowel diseases. ${ }^{14-211}$ There remains controversy as to whether these anti-IgE positive cells are plasma cells. mast cells. eosinophils. or macrophages. ${ }^{21}$ Mucosal mast cells have been shown to contain IgE in rats. ${ }^{22}$ Unfortunately, methods optimal for peroxidase staining of plasma cells are contraindicated for demonstration of mast cells in the same sections, and so it seems likely that it will require immunoelectron microscopy of the IgEcontaining cells to reveal their exact nature.

The complex immune response to gluten in coeliac disease produces an equally complex expansion of $T$ and $B$ cells in the intestinal mucosa. and also leads to an expanded intestinal mucosal mast cell population. Whether products of activated mast cells contribute to the tissue damage remains to be established. In this study, we have illustrated that with appropriate attention to methodology the morphology and numbers of mast cells in an intestinal mucosal biopsy can readily be documented. It remains now to establish whether mucosal mast cells play a part in conditions such as peptic ulcer, inflammatory bowel disease, infections, and gastrointestinal food allergies, and whether the number of intestinal mucosal mast cells relates in any way to the presence of $\mathrm{IgE}$-mediated immune reactions in the gastrointestinal mucosae.

We thank the nurses and the medical staff of the Gastrointestinal Unit for their help in carrying out this study, particularly Dr Philip Earnshaw who performed the multiple biopsies. We gratefully acknowledge the skilful technical assistance of Alexander Sutherland who processed the specimens, and of Dorothy Smith who performed the disaccharidase assays. We thank $\mathrm{Mr} \mathrm{J}$ Paul, Medical Illustration Department, University of Edinburgh, for his help with the photography and Ms A Hardy for typing the manuscript. This work was supported in part by the Deutsche Forschungsgemeinschaft DFG(STR210/1), by the Coeliac Trust, and by the National Fund for Research into Crippling Diseases.

\section{References}

1 Dollberg L, Gurevitz M, Freier S. Gastrointestinal mast cells in health, and in coeliac disease and other conditions. Arch Dis Childh 1980; 55: 702-5. 
2 Shiner M. Ultrastructural features of allergic manifestations in the small intestine of children. Scand J Gastroenterol 1981: 16: suppl 70, 49-64.

3 Kumar P. O'Donoghue DP, Lancaster-Smith $M$. Cellular changes in the jejunal mucosa following the reintroduction of gluten in treated coeliac discase. In: Edwards AM, Pepys J, eds. The mast cell. Tunbridge Wells: Pitman Medical. 1979: 647-50.

4 Kosnai I. Kuitunen P. Savilahti E. Sipponen P. Mast cells in small intestine in cow's milk protein intolerance and in celiac disease. Pediatr Res 1981: 15: 1201.

5 Strobel S. Miller HRP. Ferguson A. Human intestinal mucosal mast cells: evaluation of fixation and staining techniques. J Clin Pathol 1981; 34: 851-8.

6 Bloom G. Kelly JW. The copper pthalocyanin dye 'Astrablau' and its staining properties. especially the staining of mast cells. Histochemie 1960); 2: 48-57.

7 Brandtzacg P, Baklien K, Fausa O, Hoel PS. Immunohistochemical characteristics of local immunoglobulin formation in ulcerative colitis. Gastroenterology 1974: 66: $1123-36$

8 Lloyd G, Green FHY, Fox H, Mani V, Turnberg LA. Mast cells and immunoglobulin $E$ in inflammatory bowel disease. Gut 1975; 16: 861-6.

9 Takahashi T, Shimazu H, Yamagishi T, Masayohi T. G-cell populations in resected stomachs from gastric and duodenal ulcer patients. Gastroenterology 1980; 78: $498-504$.

10 Miller HRP, Walshaw R. Immune reactions in mucous membranes. IV. Histochemistry of intestinal mast cells during helminth expulsion in the rat. Am J Pathol 1972; 69: 195-206.

11 Enerbäck L. Mast cells in rat gastrointestinal mucosa. II. Dye-binding and metachromatic properties. Acta Pathol Microbiol Scand 1966; 66: 30)3-12.

12 Enerbäck L, Löwhagen GB. Long term increase of mucosal mast cells in the rat induced by administration of compound 48/80. (ell Tissue Res 1979: 198: 2(19-15.

1.3 Kaliner MA. Is a mast cell a mast cell a mast cell? J Allergy (lin Immunol 1980); 66: 1-4.

14 Dvorak AM. Monahan RA. Osage JE. Dickersin GR. Mast cell degranulation in Crohn's discase. Lancel 1979: 1: 498

15 Challacombe DN, Dawkins PD, Baker D. Increased tissuc concentrations of 5-hydroxytryptamine in the duodenal mucosa of patients with coealic disease. (jut 1977: 18: 882-6.

I6 Challacombe DN. Edwards JP. Baylis JM. Histamine release in post-challenge coeliac discase. Lancet 198(): 1: 212

17 Befus AD. Pearce FL, Gauldic J, Horsewood P. (joodacre RL. Cole F. Heatley RV. Bienenstock J. Isolation and characteristics of mast cells from the lamina propria of the small bowel. In: Edwards AM. Pepys J, eds. The mast cell. Tunbridge Wells: Pitman Medical, 1979: 7(12-9.

18 Rosekrans PCM, Meijer CJLM, van der Waal AM, Lindeman J. Allergic proctitis, a clinical and an immunopathological entity. Gut 1980); 21: 1017-23.

19 Heatley RV. Calcraft BJ. Fifield R. Rhodes J. Whitehead RH. Newcombe RG. Immunoglobulin $E$ in rectal mucosa of patients with proctitis. Lancet 1975: 2: 1010-2.

20) O'Donoghue DP, Kumar P. Rectal IgE cells in inflammatory bowel disease. Gut 1979; 20: 149-53.

21 Durkin HG. Bazin H, Waksman DH. Origin and fate of IgE-bearing lymphocytes. I. Peyer's patches as differentiation site of cells simultaneously bearing $\operatorname{IgA}$ and IgE. J Exp Med 1981; 154: 64(1)-8.

22 Mayrhofer G, Bazin, H, Gowans JL. Nature of cells binding anti-IgE in rats immunized with Nippostrongylus brasiliensis: IgE synthesis in regional nodes and concentration in mucosal mast cells. Eur $J$ Immunol 1976; 6: 537-45. 